\title{
The Effect of Nurse Telephone Consultation After Coronary Artery Bypass on the Autonomy Level of Elderly Patients: A Quasi-Experimental Study
}

\author{
Koroner Arter Bypass Sonrası Telefonla Hemşire Danışmanlığının Yaşlı \\ Hastaların Otonomi Düzeyine Etkisi: Yarı Deneysel Çalışma
}

\author{
(D) Figen Dığın11, (1) Ümmü Yıldız Fındık² \\ ${ }^{1}$ Kırklareli University Health High School, Department of Midwife, Kırklareli, Turkey \\ ${ }^{2}$ Trakya University Faculty of Health Sciences, Department of Surgical Nursing, Edirne, Turkey
}

\begin{abstract}
Objective: The effect of nurse telephone consultations was determined on the autonomy levels of elderly patients after coronary artery bypass surgery in this quasi-experimental study.

Methods: This study was conducted as a quasi-experimental research investigation from December 25, 2015, to January 10, 2017, at the cardiovascular surgery clinic of a university hospital and included 64 patients (32 cases, 32 control group patients). The data were collected using the "patient descriptive form," "The Functional Autonomy Measurement System," "Discharge Information Guide," and "The Telephone Consultation Follow-Up Form." The patients in the case group were provided with nurse telephone consultations six weeks after discharge. The Functional Autonomy Measurement System was re-administered to all patients at the end of six weeks. The necessary ethical and institutional approvals were obtained before the study.

Results: The mean age of the patients was $69.96( \pm 4.94)$ years, $76.56 \%(n=49)$ were males, $85.9 \%(n=55)$ were married, and $73.43 \%(n=47)$ were primary school graduates. The mean autonomy score $(-4.04 \pm 2.52)$ and the autonomy level of daily life activities of the patients $(-2.20 \pm 1.71)$ in the case group $(p=0.000)$ were significantly higher at the end of six weeks $(p<0.05)$.
\end{abstract}

Conclusion: Nurse telephone consultations increased the autonomy level of elderly patients undergoing coronary artery bypass surgery.

Keywords: Autonomy, telehealth, coronary artery bypass, elderly, nursing

öz

Amaç: Bu yarı deneysel çalışmada koroner arter bypass sonrası telefonla hemşire danışmanlığının yaşlı hastaların otonomi düzeyine etkisi belirlendi.

Gereç ve Yöntem: Çalışma 25 Aralık 2015-10 Ocak 2017 tarihleri arasında bir üniversite hastanesi Kalp Damar Cerrahisi Kliniği'nde koroner arter bypass ameliyatı olan 64 (32 deney ve 32 kontrol) yaşlı hastanın katılımı ile yarı deneysel olarak yapıldı. Veriler "Hasta Tanıtım Formu", "Otonomi Değerlendirme Ölçeği", "Taburculuk Bilgilendirme Rehberi" "Telefon Danışmanlığı İlem Formu" kullanılarak toplandı. Deney grubundaki hastalara taburculuk sonrası 6 hafta süresince telefonla hemşire danışmanlığı yapıldı. Hastaların tamamına 6 haftanın sonunda Otonomi Değerlendirme Ölçeği tekrar uygulandı. Çalışmaya başlamadan once gerekli etik ve kurum izni alındı.

Bulgular: Hastaların yaş ortalamalarının 69,95 $\pm 4,94, \% 76,6$ 'sının $(n=49)$ erkek, \%85,9'unun ( $n=55)$ evli ve \%73,4'ünün ( $n=47)$ ilköğretim mezunu olduğu belirlendi. Deney grubundaki hastaların 6 hafta sonundaki otonomi puan ortalamasının $(-4,04 \pm 2,52)$ ve günlük yaşam aktiviteleri alt boyutu otonomi puan ortalamasının $(-2,20 \pm 1,71)$ kontrol grubuna göre yüksek olduğu bulundu $(p=0,000)(p<0,05)$.

Sonuç: Telefonla hemşire danışmanlığının koroner arter bypass sonrası yaşlı hastaların otonomi düzeyini artırdığı belirlendi.

Anahtar Kelimeler: Otonomi, tele sağlık, koroner arter bypass, yaşlı, hemşirelik

Address for Correspondence: Figen Dığın, Kırklareli University Health High School, Department of Midwife, Kırklareli, Turkey Phone: +90 5056461929 E-mail: fgndgn2013@gmail.com ORCID ID: orcid.org/0000-0003-1861-0221 


\section{INTRODUCTION}

Basic changes in the body caused by old age indicate that chronic diseases replace acute diseases. One of the most significant chronic diseases is coronary artery disease, the most common cause of mortality and morbidity in the elderly (1). It leads to decreased physical, social, and mental functions, deterioration of health perception, and decreased the quality of life of patients with coronary artery disease. These patients undergo coronary artery bypass surgery, which provides blood flow to the myocardium to prolong life and reduce symptoms $(2,3)$. The literature suggests that recovery after coronary artery bypass surgery is a very complicated process that includes achieving physical, psychological, and social health to attain overall recovery $(2,3)$. Good preoperative preparation and effective postoperative care should be provided to perform surgery safely on elderly patients and reduce complications and mortality (4). The physiological changes that occur in elderly patients, the surgical methods and techniques applied, the duration of the surgery, and the length of stay in the intensive care unit and the hospital all affect the autonomy level of patients. Moreover, postoperative complications, susceptibility to chronic diseases, previous diseases, and social support systems also contribute positively or negatively to the autonomy level of patients (5). In particular, functional losses occur in the elderly after surgery due to age, depression, inadequate social support, lack of mobility, and cognitive disorders (6). During the 6-8 week postdischarge recovery period, patients experience pain management, wound care, respiratory and cardiac problems, nutritional deficiency, diarrhea, constipation, depression, and edema $(6,7)$. These issues lead to decreased autonomy levels of elderly patients after coronary artery bypass surgery (8). Therefore, elderly patients suffer temporary or permanent loss of autonomy after surgery $(9,10)$. During the recovery process, the autonomy levels of patients should be supported by home care practices (5). In line with recent technological developments, new methods are starting to deliver home care services. One of these is telehealth services. Telehealth is sharing health-related information using interactive audiovisual tools for health care applications, diagnosis, consultation, and treatment. One of the most frequently used technological methods in the telehealth system is communication by telephone (3). In telehealth services, telephone use is recommended to establish an emotional connection between the hospital and the home, support the functional independence of elderly patients, and improve the quality of care (10-12). Nurses play an active role in-home care services offered to elderly individuals. Nurses use different technological applications to follow-up with patients at home after discharge. A nurse telephone consultation, one of these applications, provides accessibility regarding the care of the elderly patient at home and maintaining that care (11). Nurse telephone consultations are highly beneficial in supporting functional independence levels of elderly patients by enabling them to participate in-home care after coronary artery bypass surgery (7). After coronary artery bypass surgery, it is recommended that nurse telephone consultation be used effectively in-home care processes for elderly patients whose autonomy levels have decreased due to both surgery and age $(7,13,14)$.

This study will determine the effectiveness of nurse telephone consultation on the autonomy level of elderly patients after coronary artery bypass surgery. It will help maintain the focus of the agenda by attracting patient and health care workers' attention. This study aims to determine the effect of nurse telephone consultation on the autonomy level of elderly patients after coronary artery bypass surgery.

\section{METHODS}

The randomized controlled study was conducted from December 25, 2015, to January 4, 2017, at the cardiovascular surgery department of a university hospital with 64 elderly patients who underwent coronary artery bypass. Based on the findings (the Functional Autonomy Measurement System (SMAF) score: -7.60 10.21) in the work titled "The validity and reliability study of the "Functional Autonomy Measurement System" among 65 years and over age group" by Tuna and Çelik (5) in 2012 the sample size was calculated as 64 at a $95 \%$ confidence interval and a 5\% margin of error. The sample included patients who volunteered to participate in the study, were aged 65 and over, were undergoing coronary artery bypass surgery, had no communication problems (i.e., no vision or hearing problems), and had no mental problems (i.e., dementia, amnesia). Also, patients (or relatives) who could communicate by telephone, were willing to volunteer to participate in the study, accepted the randomization, and had at most two chronic diseases (diabetes and/or hypertension). Patients with reoperated coronary artery bypass surgery and patients with operated coronary artery bypass surgery and valve surgery were excluded from the study.

The group to be provided telephone consultation by the researcher was determined as the case group. The other patients were included in the control group. In the study, patient in the case and control groups were followed simultaneously. The randomization was determined by the simple random randomization method with a total of 
64 patients in the case (32) and control groups (32) (Figure 1). The study sample was randomly allocated into two groups. Patients were numbered according to the order of hospitalization in the cardiovascular surgery clinic to avoid bias while performing simple randomization in the study. Even-numbered patients were included in the case group, and odd-numbered patients were included in the control group by the researcher (Figure 1).

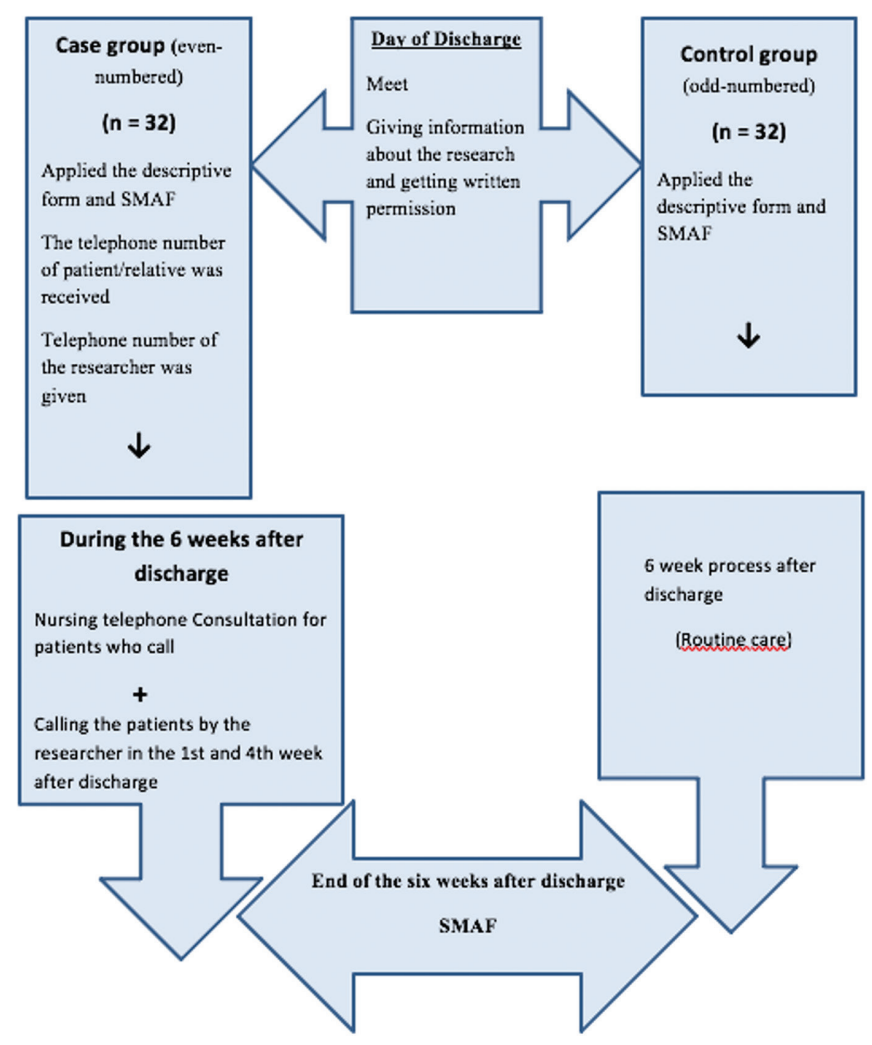

Figure 1. Flow chart of the study

SMAF: Functional Autonomy Measurement System.

The patient descriptive form consisted of 14 questions prepared by the researchers who questioned the individual patients.

The SMAF was developed in 1984 by Hebert et al. (15) to determine the level of functional independence of patients aged 65 or older. Its reliability and validity studies were performed by Tuna and Çelik (5). Each item can receive a score of between 0 and -3 , and the total dependency score of the adapted scale was -75 points. Thus, the highest possible patient score is 0 , and the lowest score is -75 . The level of autonomy increases as the patient's score approaches 0 . In the Turkish version of the scale, Cronbach's $\alpha$ coefficient for the SMAF was 0.95. In this study, Cronbach's $\alpha$ coefficient was 0.85 before discharge and 0.82 after discharge.
The Discharge Information Guide was prepared by the researcher according to the literature. The literature was reviewed to determine the educational protocols for patients undergoing coronary artery bypass surgery before discharge $(2,16,17)$.

The Telephone Consultation Follow-up form included questions about the date of the patient interview, the reason for the interview, and the proposed interventions/ recommendations. In addition, it was used to record the telephone conversations that the patients in the case group had with the researcher six weeks after discharge.

Before starting the data collection, 64 patients who were assessed for eligibility were prospectively identified. No patient was excluded from the study. After providing verbal and written information to all patients who underwent coronary artery bypass, they were asked to sign the informed consent form. During the study, the researcher collected information. The data was recorded by the researcher in line with the answers of the patients.

The patient descriptive form and the SMAF were administered to the patients in the case group who planned to be discharged within 24 hours by the face-toface interview method in the patient's room. The telephone number of each patient/relative in the case group was received, and the telephone number of the researcher was given to them. The patients were informed that they could receive a telephone consultation from the researcher concerning the problems they might experience during the home care process. According to the Discharge Information Guide, the researcher called and consulted patients in the case group during the first and fourth weeks after discharge. Besides, telephone consultations were provided to the patients who called the researcher for six weeks. Fourteen patients received counseling services by phone. Some patients called on two consecutive days, whereas other patients called once a week. It was seen that some of the patients received counseling for a few problems in one call. It was determined that the patients who received nurse counseling over the phone received consultancy for back, shoulder, waist, and leg pain for the first time, respiratory distress for the second, and wound healing for the third time. The information provided to patients by telephone consultation was recorded in the Telephone Consultation Follow-up Form. There was no time limit on-call hours for the telephone consultation provided to the patients. The researcher provided telephone consultation at every hour for patients. The researcher re-administered the SMAF to the patient in the case group by calling on the telephone at the end of the six weeks after discharge (Figure 1). 
The patient descriptive form and SMAF were administered to the patients in the control group who were planned to be discharged within 24 hours by the face-to-face interview method in the patient's room. In addition, the telephone number of each patient/relative of the control group was received. Finally, the researcher re-administered the SMAF to the patients in the control group by calling on the telephone at the end of the six weeks after discharge (Figure 1).

\section{Statıstcal Analysis}

In the study, data of 64 patients were analyzed using the Statistical Package for Social Sciences (SPSS) 21.0 program. Collected data were expressed using descriptive statistics, such as number, percentage, arithmetic mean, and standard deviation. In addition, Fisher's Exact, chi-square, independent samples t-test, the Wilcoxon signed-rank test, and Mann-Whitney $U$ test were used to compare the autonomy level of the 64 patients. The statistical significance value was accepted as $p<0.05$.

Written permission was obtained from the general directorship of the hospital and the Trakya University Medical Faculty Scientific Research Ethics Committee. Verbal and written consent was obtained from the patients participating in the study, regarding their volunteer participation and the study process, by reading the voluntary consent form. The patients participating in the study were informed that their decision to participate was their free will, and the information obtained during the study process would remain confidential and used only for this study.

\section{RESULTS}

The mean age of the patients was $69.96( \pm 4.94)$ years, $76.56 \%$ $(n=49)$ were males, $73.43 \%(n=47)$ were primary school graduates (Table 1). While the case and control groups were similar regarding sociodemographic characteristics, a higher number of patients living in urban areas in cases and a higher number of patients not using alcohol in the control group were statistically significant $(p=0.008, p=0.039$ ) (Table 1).

In the sixth week after discharge, the mean autonomy scale score of case group patients was significantly higher than control group patients $(Z=-5.565, p=0.000)$ (Table 2 ). In addition, the daily life activities sub-dimension mean autonomy scale score in case group patients in the sixth week after discharge was significantly higher than control group patients ( $Z=-5.778, p=0.000$ ) (Table 2 ).

In the sixth week after discharge, there was no significant difference between the mean scores of mental functions and communication in the case and control groups $(\mathrm{Z}=-$ 1.732, $p=0.083 ; Z=0.000, p=1.000$ ) (Table 2).

\section{DISCUSSION}

In this study, the patients given telephone consultations had a high autonomy level six weeks after discharge. Similarly, Tuna and Çelik. $(5,17)$ found a high level of autonomy in patients who received professional support and nurse consultations. Bikmordi et al. (18) reported that telephone counseling after coronary artery bypass effectively improved patients' quality of life. Moon et al. (19) found that nurse telephone consultation improved the self-care power of patients in heart failure patients. Furuya et al. (7) determined that telephone consultation was used for cardiovascular disease care, postoperative complications care, and selfcare. Also, the study by Schulz et al. (14) determined that a tele-follow-up by a nurse effectively prevented delays in postoperative recovery. Furthermore, Kleinpell and Avitall (20) stated that at home tele-follow-ups with at-risk patients undergoing coronary artery bypass surgery positively affect symptom management. A study by Lallement et al. (21) stated that $24 \%$ of elderly patients discharged after surgery experience loss of autonomy, affecting the mortality and morbidity of patients. Melholt et al. (22) stated that using telehealth applications for patient education and cardiac rehabilitation in cardiac patients is beneficial. This study and other similar studies reveal that elderly patients experience autonomy problems during the postoperative period. Our study observed that nurse telephone consultations significantly contribute to the autonomy level of patients, helping them cope with these problems. As a result, the autonomy level of patients who received nurse telephone consultations was higher.

In this study, the daily life activities sub-dimension mean autonomy scale score in the case group patients in the sixth week after discharge was significantly higher than in control group patients. Decreases in physical and psychological capacity, and aging, cause problems for the elderly about fulfilling their daily life functions. The elderly experience difficulties with daily life activities, such as bathing, dressing, urinary control, preparing food, dishwashing, laundering, shopping, house cleaning, and transportation (23). However, coronary artery bypass surgery affects the autonomy of elderly patients in performing their daily life activities $(5,17)$. A study stated that the elderly are dependent regarding daily life activities during the home care process and should be followed up (24). A study conducted by Akay and Akyol (25) stated that the daily life activities of patients who were followed up using the tele-follow-up method after 
Table 1. Demographic characteristics of the patients $(n=64)$

\begin{tabular}{|c|c|c|c|c|c|}
\hline \multirow[t]{2}{*}{ Sociodemographic characteristics } & \multicolumn{2}{|c|}{$\begin{array}{l}\text { Case } \\
\text { group } \\
(n=32)\end{array}$} & \multicolumn{2}{|c|}{$\begin{array}{l}\text { Control } \\
\text { group } \\
(n=32)\end{array}$} & \multirow[t]{2}{*}{$\begin{array}{l}\text { Test } \\
\mathrm{p}\end{array}$} \\
\hline & $\mathrm{n}$ & $\%$ & $\mathrm{n}$ & $\%$ & \\
\hline Age (Mean $\pm S D)$ & \multicolumn{2}{|c|}{$69.37 \pm 4.94$} & \multicolumn{2}{|c|}{$70.56 \pm 4.94$} & $\begin{array}{l}t=-0.986^{*} \\
p=0.328\end{array}$ \\
\hline $\begin{array}{l}\text { Gender } \\
\text { Female } \\
\text { Male }\end{array}$ & $\begin{array}{l}7 \\
25 \\
\end{array}$ & $\begin{array}{l}21.9 \\
78.1\end{array}$ & $\begin{array}{l}8 \\
24\end{array}$ & $\begin{array}{l}25.0 \\
75.0\end{array}$ & $\begin{array}{l}\chi^{2}=0.087^{\star *} \\
p=0.768\end{array}$ \\
\hline $\begin{array}{l}\text { Marital status } \\
\text { Married } \\
\text { Single }\end{array}$ & $\begin{array}{l}27 \\
5 \\
\end{array}$ & $\begin{array}{l}84.4 \\
15.6 \\
\end{array}$ & $\begin{array}{l}28 \\
4 \\
\end{array}$ & $\begin{array}{l}87.5 \\
12.5 \\
\end{array}$ & $\begin{array}{l}\chi^{2}=0.129 * \star \\
p=0.719\end{array}$ \\
\hline $\begin{array}{l}\text { Education } \\
\text { Illiterate } \\
\text { Literate } \\
\text { Primary school } \\
\text { High school } \\
\text { University }\end{array}$ & $\begin{array}{l}1 \\
2 \\
23 \\
2 \\
4\end{array}$ & $\begin{array}{l}3.10 \\
6.30 \\
71.9 \\
6.30 \\
12.5\end{array}$ & $\begin{array}{l}5 \\
1 \\
24 \\
1 \\
1\end{array}$ & $\begin{array}{l}15.6 \\
3.10 \\
75.0 \\
3.10 \\
3.10\end{array}$ & $\begin{array}{l}\chi^{2}=4.989^{\star \star} \\
p=0.284\end{array}$ \\
\hline $\begin{array}{l}\text { Working status } \\
\text { Working } \\
\text { Not working }\end{array}$ & $\begin{array}{l}4 \\
28 \\
\end{array}$ & $\begin{array}{l}12.5 \\
87.5 \\
\end{array}$ & $\begin{array}{l}2 \\
30 \\
\end{array}$ & $\begin{array}{l}6.30 \\
93.8 \\
\end{array}$ & $\begin{array}{l}\chi^{2}=0.736^{\star \star} \\
p=0.672\end{array}$ \\
\hline $\begin{array}{l}\text { Area of residence } \\
\text { Urban area } \\
\text { Rural area }\end{array}$ & $\begin{array}{l}26 \\
6\end{array}$ & $\begin{array}{l}81.3 \\
18.8\end{array}$ & $\begin{array}{l}16 \\
16\end{array}$ & $\begin{array}{l}50.0 \\
50.0\end{array}$ & $\begin{array}{l}\chi^{2}=6.926 \dagger \\
p=0.008\end{array}$ \\
\hline $\begin{array}{l}\text { Smoking status } \\
\text { Yes } \\
\text { No } \\
\text { Quit }\end{array}$ & $\begin{array}{l}1 \\
12 \\
19\end{array}$ & $\begin{array}{l}3.10 \\
37.5 \\
59.4\end{array}$ & $\begin{array}{l}4 \\
13 \\
15\end{array}$ & $\begin{array}{l}12.5 \\
40.6 \\
46.9\end{array}$ & $\begin{array}{l}\chi^{2}=2.175^{\star \star \star} \\
p=0.359\end{array}$ \\
\hline $\begin{array}{l}\text { Alcohol status } \\
\text { Yes } \\
\text { No } \\
\text { Quit }\end{array}$ & $\begin{array}{l}8 \\
16 \\
8\end{array}$ & $\begin{array}{l}25.0 \\
50.0 \\
25.0\end{array}$ & $\begin{array}{l}2 \\
25 \\
5\end{array}$ & $\begin{array}{l}6.30 \\
78.1 \\
15.6\end{array}$ & $\begin{array}{l}\chi^{2}=6.128^{\star * *} \\
p=0.039\end{array}$ \\
\hline $\begin{array}{l}\text { Number of people living together } \\
\text { Lives alone } \\
\text { Two people and above }\end{array}$ & $\begin{array}{l}2 \\
30\end{array}$ & $\begin{array}{l}6.30 \\
93.8\end{array}$ & $\begin{array}{l}3 \\
29\end{array}$ & $\begin{array}{l}9.40 \\
90.6\end{array}$ & $\begin{array}{l}\chi^{2}=0.217^{\star \star} \\
p=0.641\end{array}$ \\
\hline $\begin{array}{l}\text { Education level of the person living } \\
\text { Illiterate } \\
\text { Literate } \\
\text { Primary school } \\
\text { High school } \\
\text { University }\end{array}$ & $\begin{array}{l}2 \\
2 \\
16 \\
6 \\
4\end{array}$ & $\begin{array}{l}6.70 \\
6.70 \\
53.3 \\
20.0 \\
13.3\end{array}$ & $\begin{array}{l}6 \\
1 \\
19 \\
1 \\
2\end{array}$ & $\begin{array}{l}20.7 \\
3.40 \\
65.5 \\
3.40 \\
6.90\end{array}$ & $\begin{array}{l}\chi^{2}=6.620^{\star \star \star} \\
p=0.142\end{array}$ \\
\hline $\begin{array}{l}\text { Level of support received from the } \\
\text { Very good } \\
\text { Good } \\
\text { Poor/No support }\end{array}$ & $\begin{array}{l}11 \\
19 \\
2\end{array}$ & $\begin{array}{l}34.3 \\
59.4 \\
6.30\end{array}$ & $\begin{array}{l}8 \\
23 \\
1\end{array}$ & $\begin{array}{l}25.0 \\
71.9 \\
3.10\end{array}$ & $\begin{array}{l}\chi^{2}=1.266^{\star \star \star} \\
p=0.555\end{array}$ \\
\hline
\end{tabular}

*Independent sample t-test, ${ }^{*}$ Pearson chi-square, ${ }^{\star * \star}$ Fisher's Exact, n: Number of patients SD: Standard deviation

coronary artery bypass surgery showed improvement. Also, Rantanen et al. (3) observed that using the tele-follow-up method improved the postoperative daily life activities of patients who undergo coronary artery bypass surgery. Lafaro et al. (26) stated that telehealth perioperative physical activity intervention is feasible and acceptable for elderly patients. Also, Dinesen et al. (27) determined that telehealth applications increase the sense of autonomy and motivation of cardiac patients. Moreover, studies have found that patient counseling after discharge increased the activity, independence level, and self-care ability in patients who undergo coronary artery bypass surgery (28). Results 
Table 2. Changes in autonomy scores for both groups $(n=64)$

\begin{tabular}{|c|c|c|c|c|c|c|}
\hline \multirow{3}{*}{ SMAF } & \multicolumn{2}{|c|}{ Case group $(n=32)$} & \multicolumn{2}{|c|}{ Control group $(n=32)$} & \multicolumn{2}{|l|}{ Changes } \\
\hline & $\begin{array}{l}\text { Day of } \\
\text { discharge }\end{array}$ & $\begin{array}{l}\text { After } \\
\text { discharge } \\
6 \text { weeks }\end{array}$ & $\begin{array}{l}\text { Day of } \\
\text { discharge }\end{array}$ & $\begin{array}{l}\text { After discharge } \\
6 \text { weeks }\end{array}$ & $\begin{array}{l}\text { Day of } \\
\text { discharge }\end{array}$ & $\begin{array}{l}\text { After discharge } \\
6 \text { weeks }\end{array}$ \\
\hline & Mean \pm SD & & & & $\begin{array}{l}\text { Test } \\
\mathrm{p}\end{array}$ & \\
\hline Activities of daily living & $-20.17 \pm 6.78$ & $-2.20 \pm 1.71$ & $-22.07 \pm 9.69$ & $-8.06 \pm 4.40$ & $\begin{array}{l}Z=-0.524 \\
p=0.600\end{array}$ & $\begin{array}{l}Z=-5.778^{\star *} \\
p=0.000\end{array}$ \\
\hline Communication & $-0.96 \pm 0.82$ & $-0.96 \pm 0.82$ & $-1.03 \pm 0.82$ & $-1.03 \pm 0.82$ & $\begin{array}{l}Z=-0.413 \\
p=0.679\end{array}$ & $\begin{array}{l}Z=-0.413^{* \star} \\
p=0.679\end{array}$ \\
\hline Mental functions & $-0.96 \pm 1.17$ & $-0.87 \pm 1.03$ & $-1.00 \pm 1.16$ & $-0.96 \pm 1.14$ & $\begin{array}{l}Z=-0.122 \\
p=0.903\end{array}$ & $\begin{array}{l}Z=-2.216^{\star *} \\
p=0.829\end{array}$ \\
\hline Total & $-22.10 \pm 7.02$ & $-4.04 \pm 2.52$ & $-24.10 \pm 9.81$ & $-10.06 \pm 4.40$ & $\begin{array}{l}Z=-0.638 \\
p=0.523\end{array}$ & $\begin{array}{l}Z=-5.565^{\star \star} \\
p=0.000\end{array}$ \\
\hline
\end{tabular}

n: Number of patients, SD: Standard deviation, SMAF: Functional Autonomy Measurement System.

*Wilcoxon signed-rank t-test, **Mann-Whitney U test

NOTE: No statistical comparison was made on the day of discharge or six weeks after discharge because communication sub-dimension scores were the same

of studies show that nurse telephone consultation after coronary artery bypass surgery increased the autonomy level of elderly patients concerning daily life activities.

\section{Study Limitations}

These results cannot be generalized because they provide a single-center experience. At this point, multicenter studies should be performed.

\section{CONCLUSION}

In this study, there was a statistically significant difference between the functional autonomy level in patients in the case and control groups. Furthermore, it was revealed that nurse telephone consultations increased independence and autonomy, especially regarding the daily life activities of elderly patients who had undergone coronary artery bypass surgery. In light of these results, we recommend nurse telephone consultations to increase the autonomy level of elderly patients undergoing coronary artery bypass surgery.

\section{ACKNOWLEDGMENTS}

We would like to thank all the patients who took part in the study.

\section{ETHICS}

Ethics Committee Approval: The study were approved by the Trakya University Medical Faculty Scientific Research Ethics Committee (Protocol number: B.30.2.T RK.0.20.05.04/050.04.02).
Informed Consent: Consent form was filled out by all participants.

\section{Authorship Contributions}

Surgical and Medical Practices: F.D., Ü.Y.F., Concept: F.D., Ü.Y.F., Design: F.D., Ü.Y.F., Data Collection or Processing: F.D., Analysis or Interpretation: F.D., Ü.Y.F., Literature Search: F.D., Writing: F.D., Ü.Y.F.

Conflict of Interest: No conflict of interest was declared by the authors.

Financial Disclosure: The authors declared that this study received no financial support.

\section{REFERENCES}

1. Graf C. Functional decline in hospitalized older adults. Am J Nurs 2006;106:58-67.

2. Korkmaz FD, Alcan AO, Aslan FE, Çakmakçı H. An evaluation of quality of life following coronary artery bypass graft surgery. Turk Gogus Kalp Damar 2015;23:285-94.

3. Rantanen A, Tarkka MT, Kaunonen M, Tarkka M, Sintonen H, Koivisto AM, et al. Health-related quality of life after coronary artery bypass grafting. J Adv Nurs 2009;65:1926-36.

4. Aygin D. Yaşlı cerrahisinde bakım. Aslan FE (Ed). Cerrahi bakım vaka analizleri ile birlikte. Ankara: Akademisyen Tıp Kitabevi, 2017:181247.

5. Tuna Z, Çelik SS. The validity and reliability study of the "functional autonomy measurement system" among 65 years and over age group. European Geriatric Medicine 2013;4(supplement 1):97.

6. Mohanty S, Rosenthal RA, Russell MM, Neuman MD, Ko CY, Esnaola NF. Optimal Perioperative Management of the Geriatric Patient: A Best Practices Guideline from the American College of Surgeons NSQIP and the American Geriatrics Society. J Am Coll Surg 2016;222:930-47. 
7. Furuya RK, Mata LR, Veras VS, Appoloni AH, Dantas RA, Silveira $R C$, et al. Original research: telephone follow-up for patients after myocardial revascularization: a systematic review. Am J Nurs 2013;113:28-31.

8. Demir N. Determining functional autonomy level of elderly patients in the preoperative period (thesis). Ankara, Gazi University, Health Science Institute, 2014.

9. Malani PN, Vaitkeviciu PV, Orringer MB. Perioperative Evaluation and Management. (In: Halter JB, Ouslander JG, Tinetti ME, Studenski S, Hıgh KP, Asthana S. (ed). Hazzard's Geriatric Medicine And Gerontology. Mc Graw Hill Medical, Sixth Edition, 2009, 40738.

10. De Cola MC, Maresca G, D'Aleo G, Carnazza L, Giliberto S, Maggio MG, et al. Teleassistance for frail elderly people: A usability and customer satisfaction study. Geriatr Nurs 2020;41:463-7.

11. Hintistan S, Çilingir D. A current approach in nursing practice: telephone usage. Journal of Education and Research in Nursing 2012;9:30-5

12. Guidelines for Telenursing Practice. 2002. Registered Nurses' Association of Nova Scotia, www.rnans.ns.ca. Accessed April, 2020

13. Mols RE, Hald M, Vistisen HS, Lomborg K, Maeng M. Nurse-led Motivational Telephone Follow-up After Same-day Percutaneous Coronary Intervention Reduces Readmission and Contacts to General Practice. J Cardiovasc Nurs 2019;34:222-30.

14. da Silva Schulz R, Santana RF, Dos Santos CTB, Faleiro TB, do Amaral Passarelles DM, Hercules ABS, et al. Telephonic nursing intervention for laparoscopic cholecystectomy and hernia repair: $A$ randomized controlled study. BMC Nurs 2020;19:38.

15. Hebert R, Carrier R, Bilodeau A. The Functional Autonomy Measurement System (SMAF): description and validation of an instrument for the measurement of handicaps. Age Ageing 1988;17:293-302.

16. Dal Ü, Bulut H, Demir SG. The problems experienced by the patients at home after surgery. Medical Journal of Bakırköy 2012;8:34-40.

17. Tuna Z, Çelik SS. Discharge training and counseling: Functional autonomy and post-discharge problems of elderly patients undergoing coronary artery bypass graft surgery. Turk Gogus Kalp Damar 2014;22:570-6.

18. Bikmoradi A, Masmouei B, Ghomeisi M, Roshanaei G, Masiello I. Impact of telephone counseling on the quality of life of patients discharged after coronary artery bypass grafts. Patient Educ Couns 2017; 100:2290-6.

19. Moon MK, Yim J, Jeon MY. The Effect of a Telephone-Based Self-management Program Led by Nurses on Self-care Behavior, Biological Index for Cardiac Function, and Depression in Ambulatory Heart Failure Patients. Asian Nurs Res (Korean Soc Nurs Sci) 2018;12:251-7.

20. Kleinpell RM, Avitall B. Integrating telehealth as a strategy for patient management after discharge for cardiac surgery: results of a pilot study. J Cardiovasc Nurs 2007;22:38-42.

21. Lallement $M$, Maulat $C$, Suc $B$, Péré $G$, Lozano $S$, Bérard $E$, et al. Short-term autonomy and survival after hepatectomy in the elderly. J Visc Surg 2020;157:378-86.

22. Melholt $\mathrm{C}$, Joensson $\mathrm{K}$, Spindler H, Hansen J, Andreasen JJ, Nielsen $G$, et al. Cardiac patients' experiences with a telerehabilitation web portal: Implications for eHealth literacy. Patient Educ Couns 2018;101:854-61.

23. Karadakovan A, Çelebioğlu A, Sert ZE, Gündüzoğlu ÇN, Topçu S, Sağkal T, Bozkurt S. Determing the social support needs of elders. Journal of Ege University Nursing Faculty 2017;33:64-75.

24. Şahbaz M, Tel H. Determination of the relationship between the dependence status on daily living activities and home accidents among 65 years of age and older individuals living at home. Turkish Journal of Geriatrics 2006;9:85-93.

25. Akay B, Akyol AD. Investigation of the effect of tele monitoring on the self care agency in patients with chronic heart failure. Turk $J$ Card Nur 2014;5:75-88.

26. Lafaro KJ, Raz DJ, Kim JY, Hite S, Ruel N, Varatkar G, et al. Pilot study of a telehealth perioperative physical activity intervention for older adults with cancer and their caregivers. Support Care Cancer 2020;28:3867-76.

27. Dinesen B, Nielsen G, Andreasen JJ, Spindler H. Integration of Rehabilitation Activities Into Everyday Life Through Telerehabilitation: Qualitative Study of Cardiac Patients and Their Partners. J Med Internet Res 2019;21:13281.

28. Aydın A, Gürsoy A. The care needs and care dependency of coronary artery bypass graft (CABG) patients after hospital discharge. Journal of Education and Research in Nursing 2019;16:814. 